\title{
Chapter 11 \\ Sustainable Community Transformation \\ Process. The Role of Capacity Building in Sumba, Indonesia
}

\author{
Catharina Any Sulistyowati and Renny Nurhasana
}

\begin{abstract}
This chapter is about the role of capacity building of local NGOs in Sumba, a poor island in the Eastern part of Indonesia. It is part of a larger initiative referred to as Sumba Iconic Island (SII), which aimed to solve poverty problems, transforming unequal gender relations while at the same time mitigating climate change. This study traced what happened after six years after the project ended. It is done by exploring the project documentation and conducting interviews with Hivos staff and the alumni representatives. We find that it has improved nature, community wellbeing, women leadership, and more equal gender relations. We conclude that: (1) transformation is not a linear process; (2) the changes toward the vision are not direct but tortuous; (3) there are unintended consequences, which can be positively or negatively influence the initial goal, and (4) the capacity to analyze the situation, reflect, and create action is crucial in the transformation process.
\end{abstract}

Keywords Capacity building $\cdot$ Participatory learning $\cdot$ Community transformation $\cdot$ Sustainable development $\cdot$ Women empowerment $\cdot$ NGO

\subsection{Introduction}

Sumba is an island of eleven thousand $\mathrm{km}^{2}$ located in East Nusa Tenggara Province. It is one of the poorest provinces in Indonesia, with more than 700 thousand inhabitants. Most of the region are rocky with thin topsoil (Fig. 11.1). The forest covers only less than $10 \%$ of its area. It has a dry climate, with 3-4 months of the rainy season and 89 months of the dry season. The ecology of Sumba affects water availability and soil fertility, the essential elements for agriculture and livestock systems on this island. Both activities are crucial for the food supply of the community (Sulistyowati, 2014).

Most of the Sumba people are subsistence farmers and ranchers. They live scattered across the island. Women play a very crucial role in the food supply. Sumba women spend most of their time finding water and undertaking subsistence farming

C. A. Sulistyowati $(\varangle) \cdot$ R. Nurhasana

School of Strategic and Global Studies, Universitas Indonesia, Jakarta, Indonesia

e-mail: catharina.any@ui.ac.id 


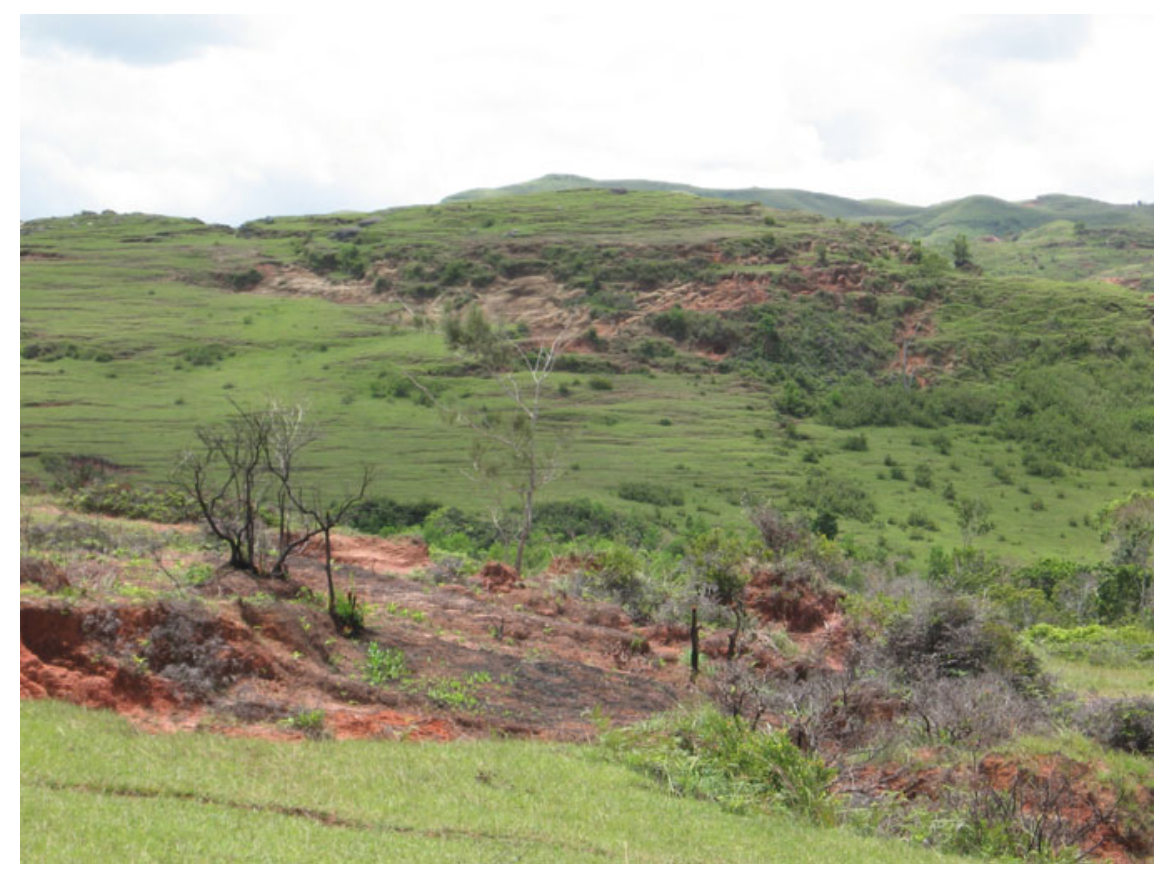

Fig. 11.1 Landscape in East Sumba during the rainy season. Source KAIL Project Documentation, 2015

to produce food stocks throughout the year. In addition, women are also in charge of cooking, gathering firewood, and maintain small livestock. With this kind of work pattern, women spend most of their time on domestic work to meet the various needs of the household. After accomplishing domestic work, women use their time to weave. They make sarung (Indonesian skirt) for additional income or customary purposes (Sulistyowati, 2014).

In Sumba, tradition plays a central role in the social system and culture. Both Sumba men and women spend considerable time for these various cultural activities. Birth, death, marriage, and looking after sick relatives are examples of cultural activities. The caste system creates a gap in the decision-making, ownership of assets, and income in Sumba society. There is also a gap between men and women. Men have greater power in terms of asset ownership and decision-making power (Sulistyowati, 2014).

Hivos, an international NGO based in the Netherlands, initiated Sumba Iconic Island (SII) Project in 2010. The vision of SII is to ensure the supply and utilization of new and renewable energy sources to promote an inclusive and gender justice economy for improving the welfare of the Sumba people. The goals of this program are that by 2025 there will be (1) an increase in energy access for Sumba people, (2) an increase in the security of energy supplies which are from new and renewable energy, (3) sufficient energy infrastructure, (4) an increase in the efficient use of 
energy, and (5) development of the industry and the regional economy to increase the purchasing power of energy (Sulistyowati, 2014).

Through the SII, Hivos hopes to intervene above conditions for creating a better life for the Sumba people. Specific conditions expected by Hivos are as follows: increasing community access to energy, increasing the security of energy supplies from the renewable energy source, availability of sufficient energy infrastructure, increasing the efficient use of energy, the development of inclusive and gender justice industry, and regional economy, so it can improve people purchasing power of energy, as well as empower women economically and socially. NGOs, government, indigenous leaders, community groups, and schools are stakeholders involved in this transformation process (Sulistyowati, 2014).

In 2014-2015, Hivos funded a capacity-building project for five local NGOs and supported them with one-year funding for women empowerment activities in their selected sites (KAIL Team, 2015). This chapter describes the process of that capacitybuilding program and what has changed from that time until now. It focuses on the individual transformation process and how it has influenced the transformation at higher levels.

\subsection{Methods}

The information in this article was collected from (1) the first author involvement in this project as the capacity-building project leader for five local NGO staffs in Sumba (2014-2015), (2) collection of field notes, reports, and publications, (3) interviews with the representative of alumni of the capacity-building program, and Hivos staff based in Sumba. During the interviews, the three questions were-what changes have happened at the personal, organization, and community levels because they participated in the capacity-building program. The interview could go further based on the interviewee's answers.

The first author of this article had the opportunity to be part of the transformation process through her involvement as the project evaluator for the micro-hydro project in Sumba in 2012 and as the project leader in the one-year capacity development program for local NGOs in Sumba in 2014-2015. During that involvement, she had the opportunity to stay for a few days with a Sumba family at the Kamanggih village in 2012 and seven-ten days of travel each month for facilitating the workshops, monitoring, and evaluation during the capacity-building process in 2014-2015 (KAIL Team, 2015; Sulistyowati \& Kurniawan, 2012). This experience also contributes to the detailed description presented in this article. 


\subsection{The SII Capacity-Building Program for NGOs in Sumba, 2014-2015}

This capacity-building project was to prepare individuals and local organizations in Sumba to be involved in a transformation process across the island. Hivos selected five key local NGOs in Sumba to be involved in that process. Hivos assigned the KAIL team to facilitate this capacity-building process. KAIL is an NGO based in Bandung that specialized in facilitation and capacity building for change agents toward a just and sustainable future. It is well known for its expertise in using systems thinking for designing transformation processes toward sustainable development. The capacitybuilding process consisted of the following components, i.e., (a) planning workshop, (b) series of capacity-building workshops, and (c) coaching services. Below is a more detailed description of each process (KAIL Team, 2015; Sulistyowati \& Kurniawan, 2012).

The planning workshop was in Waingapu, on July 21-25, 2014. In this workshop, each NGO presented its one-year project plan for women's empowerment in their community. In this workshop, participants discussed problems and strategies using systems thinking, resulting in the revised project proposal based on the leverage points identified during the workshop. Hivos reviewed the revised proposal and provided grants for each NGO to implement the project for one year from September 2014 to August 2015 and capacity-building support for the project implementation. Each NGO could send two representatives to join this capacity-building program (Sulistyowati, 2014, 2015).

In this planning workshop, the participants were introduced to systems thinking for project planning. It consisted of the following process: (1) visioning process of sustainable future for each community, (2) mapping the problems and opportunities of the current situation, (3) designing pathways for change from the current situation to the vision, (4) finding leverage interventions, and (5) planning specific actions. The participants worked in a small group of each NGO were assisted by a group facilitator, who became their coach for a year of project implementation. The participants shared their group discussion results after each stage and got feedback from other participants and the facilitator team (Sulistyowati, 2014).

During the project implementation, participants joined the series of capacitybuilding processes. These processes aimed to equip participants with the knowledge and skills to implement their project. The facilitator team reviewed the results and feedback from each workshop, analyzed them, found the gaps, and developed content and process for the next stage (KAIL Team, 2015).

There were several aspects of these programs as follows: personal leadership (personal visioning, time management, finance management), team building (group visioning, team learning, and collaboration), community organizing (participatory mapping and community planning), sustainable development (principles, renewable energy, and sustainable economy), gender awareness, business management (finance, marketing, value chain), project management (planning, monitoring, evaluation, and reporting), and project documentation and publication (Sulistyowati, 2015). 


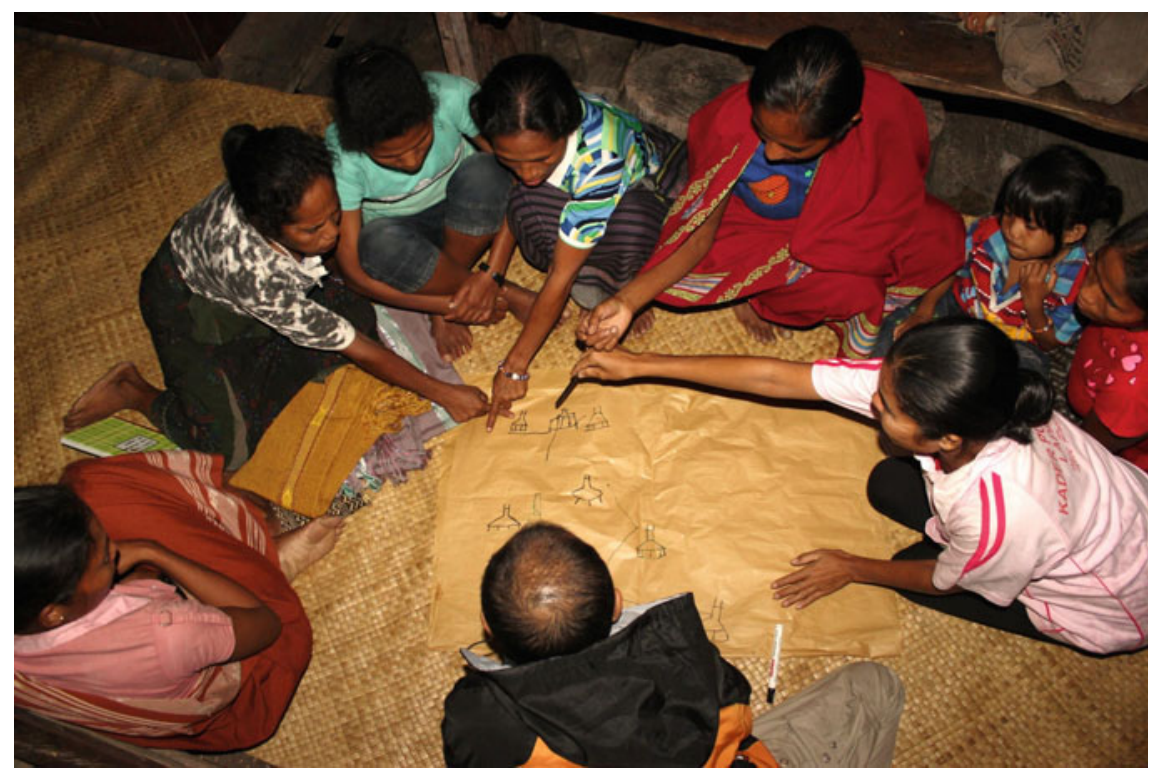

Fig. 11.2 Coaching session in the community. Source KAIL Project Documentation, 2014

This project used various methods depends on the characteristic of the content and the participants' condition. As an example, for community mapping and planning, the workshop was done in the community (Fig. 11.2) so that participants could apply concepts and methods directly in the field. After the workshop, all participants applied the skills and knowledge in their communities (KAIL Team, 2015).

For more conceptual content like principles of sustainable development, the workshop was in a classroom with a combination of lectures, group discussion, individual work, and games. The systems thinking playbook (Sweeney \& Meadows, 1995) was one of the references used. Games were helpful to explain complex issues such as ecological carrying capacity in a way that was easier for participants to understand and remember (KAIL Team, 2015).

Discussing participants' cases were effective in more technical contents such as finance and time management. The participants could practice the principles with their cases and gain direct results from them. Issues that emerged from that practice were then discussed in the plenary so that everybody could learn from it. Other technical content which interested participant was making video documentation and the use of social media. Since mobile phones and the Internet were not widely available in Sumba in 2014, this topic was relatively new for the participants. They learned how to write their field stories and put them in the blog or Facebook. They also made videos of their work (KAIL Team, 2015; Sulistyowati, 2015; KAIL Team and Sumba Capacity-building Participants 2015) .

For content like personal leadership and group leadership, we found a place where participants could have their own time, relaxing together in a circle, and discussing 


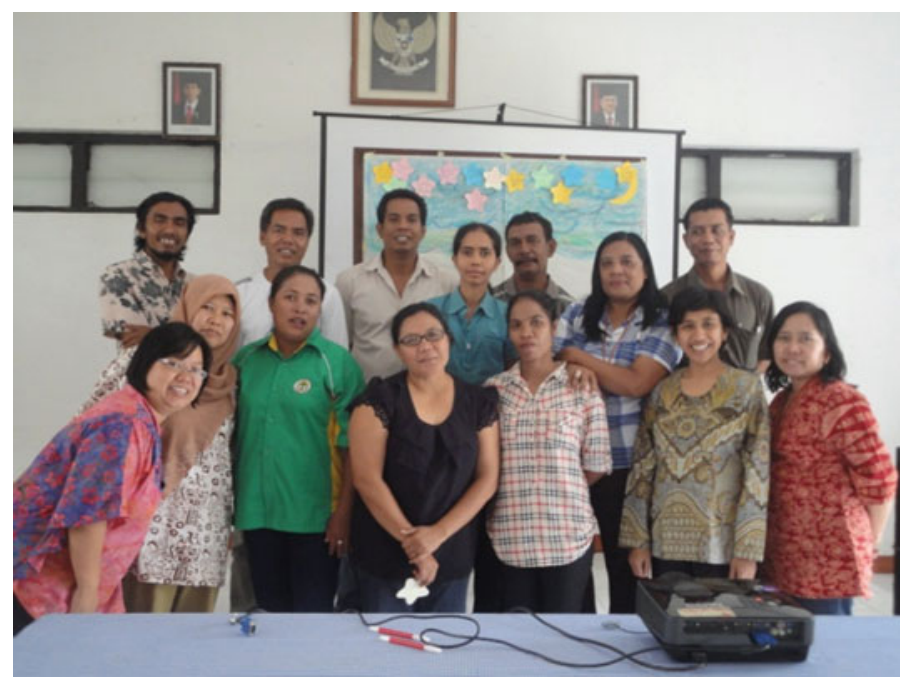

Fig. 11.3 KAIL facilitator team and the capacity-building participants. Source KAIL Project Documentation, 2015

any issues, such as their frustration as a change agent for sustainable development. It formed a safe container for each participant to support each other (KAIL Team, 2015).

Besides regular workshops, coaching was the central element of this capacitybuilding program. The coaching session was at the individual and organizational levels. During personal coaching, the participants could pick any issues they would like to discuss with the coach. The coaching session could be conducted in their free time during the workshop, usually in the evening. The individual coaching was voluntary. The organizational coaching was part of the workshop schedule. It was mainly on project management to check the stage of their project implementation and if some issues need to be solved. Sometimes issues emerged during group/individual coaching, which would be discussed during the next session or in the next workshop, depending on the urgency and time availability. Each group had one coach, who assisted them from the planning until the evaluation workshop. The participants could also contact their coach through email/phone (KAIL Team, 2015). The facilitator team and capacity-building participants are depicted in Fig. 11.3.

\subsection{The NGO Projects}

Five NGOs selected for this capacity-building program were Yayasan Peduli Kasih (Sandika), Yayasan Wali Ati (Yasalti), Lembaga Pelita Sumba (Pelita), Yayasan Sosial Donders (Donders), and Yayasan Bahtera (Bahtera). The focus of their projects 
was women's empowerment through sustainability initiatives at the community level. The projects supported were for salt producers in East Sumba (Sandika), for weaver women in East Sumba (Yasalti), Central Sumba (Bahtera), and Southwest Sumba (Donders), and for farmers in East Sumba (Pelita) (Arwida, 2015; KAIL Team, 2015).

Despite differences in geography and type of activities, the projects shared some similar women problems in Sumba. Firstly, Sumba women had to spend much time doing domestic work, such as collecting water and preparing food. Some women had to walk for three hours every day to go back and forward to collect water for the family (Sulistyowati, 2014; Sulistyowati \& Kurniawan, 2012). They also had to spend significant time preparing, cooking, and cleaning up. Women further had to collect the wood for cooking. Most families in Sumba used the traditional stove for cooking. If they cooked inside the house, the smoke from the stove would fill the kitchen. It was not healthy, especially for women who spent much time in the kitchen (Sulistyowati \& Kurniawan, 2012). Many communities in Sumba at that time still did not have electricity. In that situation, it was hard to do productive activities and learning during the evening (Sulistyowati \& Kurniawan, 2012; Sulistyowati, 2014; Hivos Web site $2021^{1}$ ).

Secondly, there was little room for women to gain economic benefit from their productive work. Many women had some skills which enable them to produce something to earn some money to increase the family income, such as making some beautiful woven fabric. However, since their time for domestic work was plenty, they had limited time for doing this. If they had the products to sell, they had to go to the market. Since the market was far from their home, they had to spend some time and money to go there so that the margin from their product sales was not much. So far, they had asked their husband to sell their woven fabric. When helping their wife selling their products, some husbands used part of the money for cigarettes, gambling, and drinking. Therefore, women only got a smaller fraction of the income. Another option was to sell the product to a middleman, who bought products at a low price (KAIL Team and Sumba Capacity-building Participants 2015; Sulistyowati, 2014).

The other problem was related to the environmental condition. As a dry island, Sumba had limited water resources. People adjusted their planting season with rainfall. During the rainy season, they planted corn and rice as their staple food subsistence. Lack of water made planting vegetables in the backyard difficult. This condition influences their food stock as well as food expenses (Sulistyowati, 2014).

\subsection{Six years Later}

In May-June 2021, we interviewed three alumni of the capacity-building program, representing three organizations. We wanted to know what changes had happened from 2015-2021, six years after the capacity-building program ended. We also aimed

\footnotetext{
${ }^{1}$ https://hivos.org/program/sumba-iconic-island-initiave/ as on 30.06.2021. For more detailed information about Sumba Iconic Island visit https://sumbaiconicisland.org/.
} 
to understand how the capacity-building process has influenced their life and their work. At the time, we could not interview the other two organization representatives due to limited communication access. Below is the summary of the interview results.

\subsubsection{Story from Trouce Landukara (Sandika, East Sumba)}

Trouce Landukara (Ibu Oce) was one of the participants from Sandika, East Sumba. With her colleague, Darius Dadi Manumesa, she set up Sandika. In 2014, Sandika was a small organization, with both of them as the founders and the staff. They assisted a community in Pamalala village in East Sumba, which produced salt for a living. In 2015, we visited the salt production site in the coastal area to meet the women there. They were poor women who produce salt in wooden huts on the coast. They collected wood on the beach and dried them for fuelwood to make salt. The salt production process was simple. Traditionally, it used a wooden furnace which created plenty of smoke. With technology improvement, they could use a new type of furnace that produced less smoke. It improved women working conditions to be healthier. These women set up a saving and loan group to help them access the production capital and financial security in difficult times (KAIL Team, 2015; Landukara, 2021).

In 2021, Sandika has grown into a larger organization with seven staff members. Ibu Oce is still the leader of Sandika. Her current influence is much beyond Sandika. For Ibu Oce, the most influential contribution of the capacity-building process was finance management. That training content had opened her mind to several principles to live financially independent so that she had the freedom to do her social work without any dependency on external funding. She likes to do mentoring activities that she is currently doing, but she does not want to be financially dependent on these activities, which depended on the donor's money. More than that her position as a single parent required her to take care of all financial matters by herself. So, she started her own business (Landukara, 2021).

Ibu Oce loves sewing and used that skill to make sarung kambuli (sarung), a scabbard used by Sumba women. This sarung is mostly for cultural events such as death, birth, and marriage ceremonies. In Sumba, those ceremonies require cloth to be worn or given to the party holding the ceremony. This type of sarung uses clothes purchased at the local shop. A sarung needs $1.60 \mathrm{~m}$ of cloth which costs her about fifty thousand rupiahs (around 3.5 US\$) per meter. It was then sewn into a sarung and embroidered with the motif required by the buyer. In the past, Ibu Oce asked somebody else to draw the motif for her, but now, she can do her drawing. By drawing on her own, Ibu Oce can better understand consumer desires. Once finished, the sarung price is between Rp. 350.000 to Rp. 650.000 (around 23-43 US\$) per piece, depending on its quality (Landukara, 2021).

From this business, Ibu Oce has managed to live independently. She teaches these skills to her siblings, especially those who do not have a job yet. From this business, they can support their families and send their children to school. One of them even can finance going to college. Apart from family, Ibu Oce also formed groups. Each 
group consists of 10-32 women involves in these sarung-making groups (Landukara, 2021).

To market her sarung, Ibu Oce uses social media, such as Facebook. Although she has already involved many women as part of the sarung-making groups, sometimes Ibu Oce gets too overwhelmed when she receives many orders. That is why she did not accept pre-finance because she is afraid of failing to finish on time. Customers only pay after they receive their sarung. She also made a stock of sarungs because some customers would like to buy ready-to-use sarungs. Ibu Oce accepts orders at least a month in advance. Only in selected cases, she accepts orders with less time to deliver. She would like to maintain the quality of the sarung. It should be made carefully and not in a hurry. It takes about two days to make a small sarung and 4-5 days for a large one (Landukara, 2021).

To maintain the quality, before giving a sarung order to the group, she first assessed the capacity of each group member. She informed them the quality standards of the sarung and taught them how to achieve these standards. She then ordered a sarung and to see the results. Based on the results, she provided suggestions for necessary improvements. When they were good, she could give them orders for more sarungs. Ibu Oce provided all the materials for making the sarung, such as clothes, thread for embroidering, and the embroidery motif. They just had to focus on the sarung making. Ibu Oce would come at the appointed time to take the sarung and make the payment (Landukara, 2021).

From her sarung business, Ibu Oce has the opportunity to continue her social work, such as the community work in Sandika. She has involved in politics. Ibu Oce was approached by a political party and become the woman candidate in the local election. She lost in that election due to the lack of preparation and experience. However, it was a valuable lesson for her. She was one of the facilitator team for the Hivos renewable energy project. Through that involvement, she had the opportunity to empower women in many places in Sumba. She also had experiences in another province and abroad (Landukara, 2021). Now, she is the Haba Hammu leader, a network consisting of eight local NGOs in Sumba, namely Pelita, Sandika, Bahtera, Donders (the capacity-building participants), and other four organizations recruited in 2020, namely Satu Visi, Humbai Lulu, Sabana Sumba, and KPI (Kefi, 2021; Landukara, 2021; Opang, 2021).

\subsubsection{Story from Imelda Sulis (Donders, East Sumba)}

For Imelda Sulis (Ibu Sulis), a transformation process was happening at three levels. Firstly, at the individual level. It aided her role as program manager. It helped her doing her organizational tasks, such as planning, problem analysis, strategy formulation, collaboration, and program integration. She learned a lot from the theory of change approach (ToC) (Sulis, 2021). In the theory of change approach, the participants draw causal systems maps to design leverage intervention toward their vision. 
ToC is very useful for project design, proposal formulation, and community planning (KAIL Facilitator Team, 2015; Sulistyowati, 2014).

This personal transformation also transforms Ibu Sulis' organization. She disseminated the knowledge and skills to the 26 field workers of her organization through their internal meetings and mentoring process. For example, they used ToC for designing programs on disaster management, energy, and environmental programs. It helped them to write a proposal and get funding from donors. Ibu Dewi and Ibu Epin, two other capacity-building participants from Donders applied the skills in their fieldwork on women empowerment and sustainable agriculture. They use the causal diagram to map community problems and discuss them to seek a solution together with the community. Until now, there are no single fixed procedures in applying ToC. They modified the tools according to local context and their specific needs (Sulis, 2021).

To spread the knowledge within Donders was not an easy process. They created regular discussion events to facilitate sharing and learning processes internally, where they could learn from each other. The participants complement each other so that all of them could master all contents. It was also not easy to understand the tools at the theoretical or conceptual level, and therefore, they also facilitated the learning directly in the field by practicing together. Solving community problems using a regular type of workshop was not effective. It was time-consuming and hard to be followed by all participants. According to Ibu Sulis, the community was more enthusiastic in discussing the problems and solutions in the field (Sulis, 2021).

Funding support from Hivos focused on strengthening groups of Sumba weavers. In 2021, these women's groups are still active. Donders organized the marketing for the groups' products. Besides sarung, now, they can also create various woven products, such as scarves and prayer mats. Donders sells weaving products, coffee, moringga leaf product, and some other products. They have a shop and training facility, which was very basic in 2014. Now, it is equipped with air conditioning and a fan. They also built a meeting room on the 2 nd floor (Sulis, 2021).

At the community level, some of the women are not only active in their community. They were weaving teachers in some weaving training sessions in Sumba. One of the active members of the group, Ibu Kristina, was involved in public spaces. She became the head of the neighborhood (Ketua Rukun Tetangga), as the health/malaria cadres, and participated in the village meeting (Musrenbang). With better knowledge, women can play more roles in society (Sulis, 2021).

Ibu Sulis also observed several other changes in the community. Women's involvement in the productive and public role brought about changes in the community division of labor. In the past, it was hard to find a man who replaced his wife to sell vegetables in the market. Now, we can find some of them in the market. The discussion on the division of roles between women and men was increased. There was a changing perspective on women's involvement in productive and public activities. In the past, women were not involved in village planning meetings. Now, women have to be involved in decision-making, especially regarding programs that are related to them. In Donders'-assisted villages, perhaps around $65 \%$ of those villages have already acknowledged the importance of women's participation. So far, the response from the other women is positive. They would like to be involved also (Sulis, 2021). 
The social change process toward gender equality and the improvement of women's wellbeing is still part of the advocacy agenda of Donders. The change required mindset changes. It requires collective awareness in all Donders staff as well as support from the government and communities. That is why education/capacity building for staff and the communities are central in Donders' work. They traced the change through the monitoring and evaluation process involving staff and community members, including women, men, children, and other minority groups (Sulis, 2021).

\subsubsection{Story from Yulius Opang (Pelita Sumba Foundation)}

Yulius Opang (Om Lius) is the head of Yayasan Pelita Sumba (Pelita). The most valuable and unique contents for Om Lius were the value chain analysis and the theory of change (ToC) (Opang, 2021). Value chain analysis calculates and compares the distribution of efforts and benefits along the product chains. Based on that calculation, they can determine the fair price for their product. It is fundamental knowledge because usually, the community did not include their labor in the production cost. This labor cost is what they usually called profit. With this skill, they can determine their product price and have a better bargaining position in the market (KAIL Team, 2015). ToC improved Pelita's skills in project design and fundraising (Opang, 2021).

Hivos fund was for strengthening farmers' groups to plant vegetables in forest areas. The community got the right to cultivate the forest from the Ministry of Forestry. The agreement was that the community could grow vegetables as long as they also plant fruits and timber. Vegetables provided them with short-term cash, while fruits would provide them with income after five years or later without cutting the trees. Through this intervention, the forest could have conservation as well as productive purposes. After that project completion, Pelita was no longer getting support from Hivos. However, they managed to get funding from other sources where they can have the opportunity to continue their community organizing work as well as forming new vegetable farmers groups (Fig. 7) (Opang, 2021).

Farmer groups in Meurumba are still active in producing vegetables. Farmers transport their harvest to the weekly market in the sub-district or to the market in Waingapu. Like six years ago, they still plant chili. Chili is easy to carry and can grow better in the rainy season compared to shallots and tomatoes. Fruit trees and wood planted in forest lands are already growing high and block the sunlight from reaching the ground. Starting this year, they will harvest candlenuts. In the long term, candlenut is the next source of income for farmers. Farmers can harvest the candlenut, while the Ministry of Forestry will ensure the conservation purpose (Opang, 2021).

According to Om Lius, there are many challenges in establishing an equal role between men and women. In East Sumba, leaders are identical to men. The enabling process of women's involvement in the public sphere is as follows: They practiced talking among women first, then after they get used to it, they can speak in public. Their experience in Meurumba village concluded that it was less effective to address 
gender issues by only involving women. Without men's support, the involvement of women will only occur during project time. After the project ends, the men/women relations will be back to their original habits. When husband and wife both gain gender awareness, it is more effective in transforming their relations (Opang, 2021).

In 2021, Pelita has seven staff. Om Lius expects that all staff will have gender, poverty, and environmental awareness. Pelita focused on people who live around forests. Through working with these people, they got the opportunity to transform poverty by improving the environment. This work required Pelita staff to live in the community and have direct involvement with their problems. According to Om Lius, this is a hard job with little financial reward compared to the income from other professions. Therefore, it is a challenge to find cadres from the younger generation (Opang, 2021).

Despite this challenge, a former Pelita volunteer and staff, Rambu Tamu Ina was nominated to be the village head by the community. The election will be on August 25, 2021. When she was a volunteer at Pelita, she learned a lot from a various capacity-building processes provided by Pelita. Then, she became the community assistance for Meurumba village. If elected, she will be one of the five village heads in East Sumba. Since women leaders are rare in Sumba, even speaking in public is still rare and difficult for women; this will be one of the breakthroughs for women's empowerment (Opang, 2021).

\subsection{The Lessons and Conclusion}

From the alumni stories of capacity building six years ago, below are some lessons from the transformation process in Sumba:

- The transformation process does not occur in an instant. It is a gradual process that involves the awareness of the various parties involved in the transformation process.

- The original plan is often different from what happens in the field. On many occasions, theory, concept, and methodology need to be modified and adjusted according to the local context, resulting in a unique and rich experience from the field. Through these field experiences, knowledge will be enriched and shape further learning and actions.

- The network of people with similar visions is strategic for the success of the transformation. The network can help change agents maintain the spirit of change. Friends are valuable, especially in the time of a lonely struggle.

We conclude that transformation is not a linear process. The changes toward the vision are not linear but tortuous. Along the way to that vision, there are unintended consequences that positively or negatively influence the goal. The capacity to analyze the situation, learn, reflect, and create action is very important to the success of the transformation process. 


\section{References}

Arwida, S. D. (2015). Evaluation report of capacity building for "women and renewable energy capacity building program.” External Evaluation Report. (Unpublished).

Hivos. (2021). Sumba Iconic Island. Retrieved January 06, 2021, from https://sumbaiconicisland. org/.

KAIL Facilitator Team. (2015). Kumpulan Materi Peningkatan Kapasitas LSM Sumba (Vol. 1). (C. A. Sulistyowati, Ed.) KAIL, Bandung, West Java. Indonesia. Retrieved June 30, 2021, from http://cerita-dari-sumba.blogspot.com/p/kumpulan-materi-peningkatan-kapasitas.html

KAIL Team. (2015). Sumba Capacity Building. Final Project Report. KAIL, Bandung, West Java. Indonesia. (Unpublished).

KAIL Team and Sumba Capacity Building Participants. (2015). Cerita Dari Sumba. Retrieved December 06, 2021, from https://cerita-dari-sumba.blogspot.com/.

Kefi, R. (2021, June 3). Impact of Capacity Building in Sumba 2014-2015. (C. A. Sulistyowati, Interviewer).

Landukara, T. (2021, May 19). Impact of capacity building in Sumba 2014-2015 for Sandika. (C. A. Sulistyowati, Interviewer).

Opang, Y. (2021, June 14). Impact of capacity building in sumba 2014-2015 for Pelita. (C. A. Sulistyowati, Interviewer).

Sulis, I. (2021, May 27). Impact of capacity building in Sumba 2014-2015 in Donders. (C. A. Sulistyowati, Interviewer).

Sulistyowati, C. A. (2014). The use of theory of change for strengthening women in Sumba. KAIL, Bandung, West Java. Indonesia. Retrieved June 30, 2021, from http://cerita-dari-sumba.blogspot. $\mathrm{com} / \mathrm{p} /$ the-use-of-theory-of-change-for.html.

Sulistyowati, C. A. (2015). Capacity building program for NGOs in Sumba 2014-2015. KAIL, Bandung, West Java. Indonesia (Unpublished).

Sulistyowati, C. A., \& Kurniawan, A. (2012). Laporan Evaluasi Proyek Mikrohidro IBEKA—Hivos. Evaluation Report (Unpublished).

Sumba Iconic Island Initiative (2018). Retrieved June 30, 2021, from https:/hivos.org/program/ sumba-iconic-island-initiave/.

Sweeney, L. B., \& Meadows, D. (1995). Systems thinking playbook: Exercises o stretch and build learning and systems. Chelsea Green Publishing.

Open Access This chapter is licensed under the terms of the Creative Commons Attribution 4.0 International License (http://creativecommons.org/licenses/by/4.0/), which permits use, sharing, adaptation, distribution and reproduction in any medium or format, as long as you give appropriate credit to the original author(s) and the source, provide a link to the Creative Commons license and indicate if changes were made.

The images or other third party material in this chapter are included in the chapter's Creative Commons license, unless indicated otherwise in a credit line to the material. If material is not included in the chapter's Creative Commons license and your intended use is not permitted by statutory regulation or exceeds the permitted use, you will need to obtain permission directly from the copyright holder.

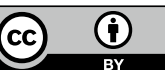

